Vol. 24, No. 1, Januari 2021, hlm. 112-123

p-ISSN: 1410-9344; e-ISSN: 2549-5631

\title{
Pendidikan Sepuluh Keterampilan Sosial untuk Anak-Anak di Desa Seririt Buleleng Bali
}

\author{
Gede Suwardika ${ }^{1}$, Dian Rahmani Putri ${ }^{2}$, I Ketut Putu Suniantara ${ }^{3}$, Kadek Masakazu \\ 1,4Universitas Terbuka UPBBJ - Denpasar \\ ${ }^{2,3}$ Institut Teknologi dan Bisnis STIKOM Bali \\ email: ${ }^{1}$ isuwardika@ecampus.ut.ac.id, ${ }^{2}$ rahmani@stikom-bali.ac.id, ${ }^{3}$ suniantara@stikom-bali.ac.id, \\ ${ }^{4}$ masakazu@ecampus.ut.ac.id
}

\section{Article Info}

Submitted: 11 March 2020

Revised: 11 June 2020

Accepted: 16 November 2020

Published: 24 December 2020

Keywords : banjar, education, ten social capabilities, CTL
Kata Kunci : banjar, pendidikan, sepuluh keterampilan social, CTL

\section{Abstract}

The role of the community is very important in the character education of children, after the role of parents and close family. In the Balinese context, the community has an institution called banjar where residents can gather to carry out any social activity. Starting from routine meetings to discuss the actual environmental conditions, religious ceremonies, public health, public facilities and infrastructures to educational activities for children. One example is the location, in the District of Seririt, Buleleng, Bali, where there are many bale banjars that are used as a place to carry out Todler Activities as well as Kindergarten, and a playground for elementary school students. Ten Social Skills Education (TSSE) which has been carried out by the community service team, helps children in finding and correcting the deficiencies of each personality through various techniques and also various materials using the Contextual Teaching and Learning (CTL) learning model, which includes a learning approach, learning strategies, learning methods and learning techniques, as well as the implementation of sharing and sharing modules for parents and teachers. The community service team invites together to implement the TSSE. The implementation of community service activities was assisted by Bidikmisi Open University Denpasar students. This activity has been carried out in each banjar for 8 months. The results achieved from this activity are changes in the attitudes of children after carrying out the activity that is becoming more polite, more confident to actively ask and answer, more focused and enthusiastic in implementing the learning process.
Abstrak
Peran masyarakat sangat penting dalam pendidikan karakter anak- anak, setelah peran orang tua dan keluarga dekat. Dalam konteks Bali, masyarakat memiliki lembaga yang disebut banjar di mana warga dapat berkumpul untuk melaksanakan kegiatan sosial apa saja. Mulai dari pertemuan rutin untuk membahas tentang kondisi 
lingkungan aktual, upacara keagamaan, kesehatan masyarakat, sarana dan prasana umum sampai dengan kegiatan pendidikan untuk anakanak. Salah satu contoh lokasi, di wilayah Kecamatan Seririt, Buleleng, Bali, di mana banyak terdapat bale banjar yang digunakan sebagai tempat untuk melaksanakan Pendidikan Anak Usia Dini (PAUD) dan juga Taman Kanak-Kanak (TK), serta tempat bermain bagi anak-anak Sekolah Dasar (SD). Pendidikan Sepuluh Keterampilan Sosial (PSKS) yang telah dilaksanakan oleh tim pengabdian masyarakat, membantu anak-anak dalam menemukan dan memperbaiki kekurangan dari setiap kepribadian melalui berbagai teknik dan juga berbagai materi dengan menggunakan model pembelajaran Contextual Teaching and Learning (CTL), yang mencakup pendekatan pembelajaran, strategi pembelajaran, metode pembelajaran dan teknik pembelajaran, serta pelaksanaan sharing dan pembagian modul untuk orang tua dan guru-guru. Tim pengabdian masyarakat mengajak bersama-sama melaksanakan PSKS. Pelaksanaan kegiatan tim pengabdian masyarakat dibantu oleh mahasiswa Bidikmisi Universitas Terbuka Denpasar. Kegiatan ini telah dilaksanakan di masing-masing banjar selama 8 bulan. Hasil yang dicapai dari kegiatan ini adalah adanya perubahan sikap anak-anak setelah melaksanakan kegiatan yaitu menjadi lebih sopan-santun, lebih percaya diri untuk aktif bertanya dan menjawab, lebih fokus, serta bersemangat dalam melaksanakan proses belajar.

\section{PENDAHULUAN}

Pembentukan karakter melalui pendidikan dasar merupakan hal yang menentukan bagaimana karakter generasi di masa depan. Oleh karenanya pendidikan dasar sangat menentukan keluaran anak-anak yang seiring waktu menjadi dewasa dan memiliki kemampuan baik dalam berpikir, berkata maupun berbuat yang memiliki nilai sesuai dengan apa yang diterima oleh masyarakat umum. Pendidikan karakter sebagai pendidikan dasarbagianakyangmenitikberatkan pada pertumbuhan fisik, kecerdasaan emosi dan spiritual, sosial emosional (sikap dan perilaku), dan komunikasi (Tanu, 2017), (Maemonah, 2012), (Izzaty, 2012). Untuk dapat memperoleh hasil generasi yang tumbuh sesuai dengan keinginan kita, ada karakter mendasar yang harus dibangun terlebih dahulu.

Gagasan kegiatan ini diinspirasi oleh Wibowo dalam bukunya Success Begins with Character - Revolusi Pendidikan Karakter. Dalam buku tersebut dijelaskan tentang hasil penelitian yang telah dilakukan di Amerika Serikat seperti tercantum dalam website theasianparent.com, bahwa ada sepuluh keterampilan sosial yang harus dikembangkan pada anak sejak Sekolah
Dasar (Wibowo, 2018). Keterampilan sosial tersebut yaitu 1) Kemampuan mendengarkan orang lain, 2) Mengikuti petunjuk, 3) Menaati peraturan, 4) Mengacuhkan gangguan, 5) Meminta bantuan, 6) Berbicara secara bergantian, 7) Berkumpul bersama orang lain, teman sebaya, saudara, dan lain-lain, 8) Bersikap tenang ketika berada di tengah banyak orang, misalnya ketika berada di mall atau dalam sebuah acara keluarga, 9) Bertanggung jawab atas segala tindakan, dan 10) Melakukan hal baik untuk orang lain.

Sepuluh keterampilan sosial ini disusun berdasarkan hasil survei yang dilakukan pada tahun 2006 terhadap 8000 guru sekolah dasar di Amerika Serikat dan penelitian selama lebih 20 tahun di berbagai sekolah dasar di Amerika Serikat. Sumber lainnya menyebutkan tentang sepuluh keterampilan sosial yang lebih kepada penerapan langsung seperti: cara berkenalan, cara melaksanakan perintah, cara meminta tolong, cara mengerjakan tugas, cara menyikapi kata 'tidak', cara berdebat dan menghormati pendapat, cara berterima kasih, cara meminta maaf, menerima kritik, dan saran dan mengontrol emosi. 
Dengan menyadari dan membangun keterampilan sosial ini, anak-anak menjadi lebih mudah dalam memperluas cara berpikir dan bertindak dalam menjalani kehidupan, serta memunculkan karakter yang baik yang dapat dirasakan oleh orang-orang di sekitarnya. Pendidikan karakter membantu anak-anak dalam menemukan dan memperbaiki kekurangan dari setiap kepribadian melalui berbagai teknik dan juga berbagai materi. Pendidikan karakter bahkan dapat dirangkaikan dengan berbagai mata pelajaran seperti bahasa bahkan matematika. Pada kenyataannya pendidikan karakter dapat dilaksanakan baik di dalam pendidikan formal maupun juga pendidikan nonformal (Saputro, 2017), (Karo-karo, 2014).

Lingkungan masyarakat adalah salah satu pihak yang juga berperan penting dalam pendidikan karakter anak-anak setelah orang tua dan keluarga dekat perlu ditopang oleh pendidikan yang baik (Ramdhani, 2014). Dalam konteks Bali, masyarakat memiliki lembaga yang disebut banjar di mana warga dapat berkumpul untuk melaksanakan kegiatan sosial apa saja. Mulai dari pertemuan rutin untuk membahas tentang kondisi lingkungan aktual, upacara keagamaan, kesehatan masyarakat, sarana dan prasana umum sampai dengan pendidikan generasi. Sebuah desa biasanya terdiri dari beberapa banjar dan dilengkapi dengan gedung serbaguna yang disebut dengan Bale Banjar. Salah satu contoh lokasi, di wilayah Kecamatan Seririt, Kabupaten Buleleng, ada banyak sekali bale banjar yang digunakan sebagai tempat untuk melaksanakan Pendidikan Anak Usia Dini (PAUD) dan juga Taman Kanak-Kanak (TK) serta tempat bermain bagi anak-anak sekolah dasar (SD) yang digunakan untuk menuangkan aktivitas kreatif bagi anak-anak (Sanjaya \& Juliarthana, 2019), (Suryawati, 2018), (Sawitri \& Nugrahandika, 2017).

Orangtua, ayah, dan ibu adalah pihak pertama yang menanamkan prinsip dan mengajarkan berbagai hal kepada anak-anak mereka, bukan hanya membebankan kepada sekolah atau pendidikan formal lainya (Hulukati, 2015), (Sudaryanti, 2012). Adakalanya orang tua merasa kewalahan menghadapi anak-anak saat ini yang sangat aktif dan terlalu diwarnai dengan kemajuan teknologi yang membuat anak-anak tampak 'hidup di dunianya sendiri'. Apabila tidak berhati-hati dan kurang bijaksana dalam mendidik, anak akan bertumbuh menjadi pribadi yang tidak mandiri, pribadi mementingkan diri dan tidak bisa bersosialisasi bahkan menjadi pribadi yang cenderung menyusahkan orang lain. Pada kesempatan ini, tim kerja pengabdian masyarakat ingin membantu warga banjar membagikan pengetahuan tentang sepuluh keterampilan sosial ini khususnya untuk anakanak. Program ini juga secara tidak langsung dapat membagikan pengetahuan kepada para orangtua dalam rangka membantu membentuk karakter anak-anak mereka. Selain ke sepuluh keterampilan sosial, pembelajaran lain juga akan dikembangkan yang berhubungan dengan pembelajaran di sekolah terutama pelajaran bahasa Indonesia, bahasa Inggris dan Matematika.

Berdasarkan pencarian pada situs web Pemerintah Daerah Kabupaten Buleleng (seririt.bulelengkab.go.id), Kecamatan Seririt mempunyai satu Kelompok Bermain, dua Taman Kanak-Kanak, satu Raudatul Atfal, tiga SD Negeri dan satu SD swasta, serta satu Madrasah Ibtidaiyah, dua SMP Negeri dan satu SMP swasta serta satu Madrasah Tsanawiyah, satu SMA, dan satu SMK Negeri. Kegiatan Pengabdian Masyarakat ini dilaksanakan untuk 75 orang peserta dari PAUD, Taman Kanak-Kanak dan Sekolah Dasar yang ada di Kecamatan Seririt. Berdasarkan pengamatan awal, ada beberapa anak yang terlihat sangat aktif namun juga memiliki potensi untuk berperilaku yang dapat menimbulkan ketidaknyamanan lingkungan sekitarnya, misalnya: perilaku yang suka membantah permintaan guru/orang tua, suka mengganggu, dan mengejek temannya.

Setelah mengamati analisis situasi yang telah diuraikan pada paragraf sebelumnya, diperoleh rumusan masalah sebagai berikut:

1. Bagaimanakah membangun karakter anak-anak di wilayah Kecamatan Seririt, Kabupaten Buleleng melalui Pendidikan Sepuluh Keterampilan Sosial?

2. Bagaimanakah cara membagikan pengetahuan tentang pendidikan karakter kepada para orangtua di wilayah Kecamatan Seririt, Kabupaten Buleleng? 


\section{METODE}

Pelaksanaan pengabdian masyarakat ini dilakukan di Desa Seririt Kabupaten Buleleng dengan jarak dari Kota Denpasar kurang lebih 80 kilometer. Permasalahan prioritas yang ditangani dalam kegiatan pengabdian masyarakat ini adalah bagaimana dapat memberikan Pendidikan Sepuluh Keterampilan Sosial (PSKS) kepada anak-anak di wilayah Kecamatan Seririt, Kabupaten Buleleng. Pendidikan dasar ini secara efektif dilaksanakan dalam kunjungan selama 3 (tiga) kali dalam sebulan. Target capaian pengabdian masyarakat ini adalah adanya pengenalan dan peningkatan keterampilan sosial anak-anak yang mencakup sepuluh aspek sebagaimana tercakup dalam materi ajar. Ruang lingkup PSKS ini adalah bagaimana membangun karakter anak-anak menjadi karakter yang berpengetahuan, mandiri, memiliki keterampilan untuk menyesuaikan diri dengan lingkungan, beretika dan berkepribadian baik, serta menaati aturan yang berlaku. Alur kerja kegiatan pengabdian masyarakat disampaikan dalam gambar 1 .

Kegiatan dilaksanakan tiga kali dalam sebulan selama dua bulan di hari minggu. Pemilihan tiga kali sebulan dimaksudkan agar pada satu hari minggu di bulan tersebut ada kesempatan anak-anak untuk berakhir pekan bersama orang tua dan keluarga. Kegiatan diawali dengan sosialisasi, yakni perkenalan dan pengenalan materi secara umum kepada anakanak didampingi dengan orangtua. Pada tahap ini disampaikan mengenai tujuan, target, dan sasaran dilaksanakannya kegiatan pengabdian masyarakat ini, serta rangkaian kegiatan program PSKS. Rangkaian kegiatan terdiri atas: pemberian materi keterampilan sosial yang dipadukan dengan pengetahuan bahasa Indonesia, bahasa Inggris dan Matematika serta budaya Bali, dengan metode ceramah, diskusi, dan belajar sambil bermain.

Dalam pengenalan sepuluh keterampilan sosial dilakukan secara formal dan informal baik melalui pembelajaran seperti di kelas maupun keteladanan. Pembelajaran merupakan kegiatan utamanya yang sudah tentu menggunakan model pembelajaran. Model pembelajaran menurut Arends (2012) adalah istilah yang digunakan untuk menggambarkan keseluruhan pendekatan atau perencanaan umum untuk sebuah instruksi. Kelengkapan dari modelmodel pembelajaran adalah kerangka teoretis, orientasi tentang apa yang harus dipelajari oleh siswa dan prosedur, serta struktur pengajaran yang spesifik. Arends juga menyatakan bahwa aspek yang terpenting dalam pekerjaan para pengajar adalah bagaimana menyiapkan instruksi langsung kepada para siswa di dalam kelas. Sebuah model pembelajaran didefinisikan oleh Arends lebih dari pada metode atau strategi tertentu melainkan keseluruhan perencanaan, atau pola pembelajaran untuk membantu para siswa mempelajari jenis-jenis ilmu pengetahuan, sikap ataupun keahlian tertentu. Chatib (2019) menyatakan bahwa model pembelajaran adalah sebuah sistem proses pembelajaran yang utuh, mulai dari awal hingga akhir. Model pembelajaran melingkupi pendekatan pembelajaran, strategi pembelajaran, metode pembelajaran dan teknik pembelajaran. Model pembelajaran yang digunakan adalah Contextual Teaching and Learning (CTL) mencakup: pendekatan pembelajaran, strategi pembelajaran, metode pembelajaran, dan teknik pembelajaran seperti yang dinyatakan oleh Johnson (2012). CTL adalah

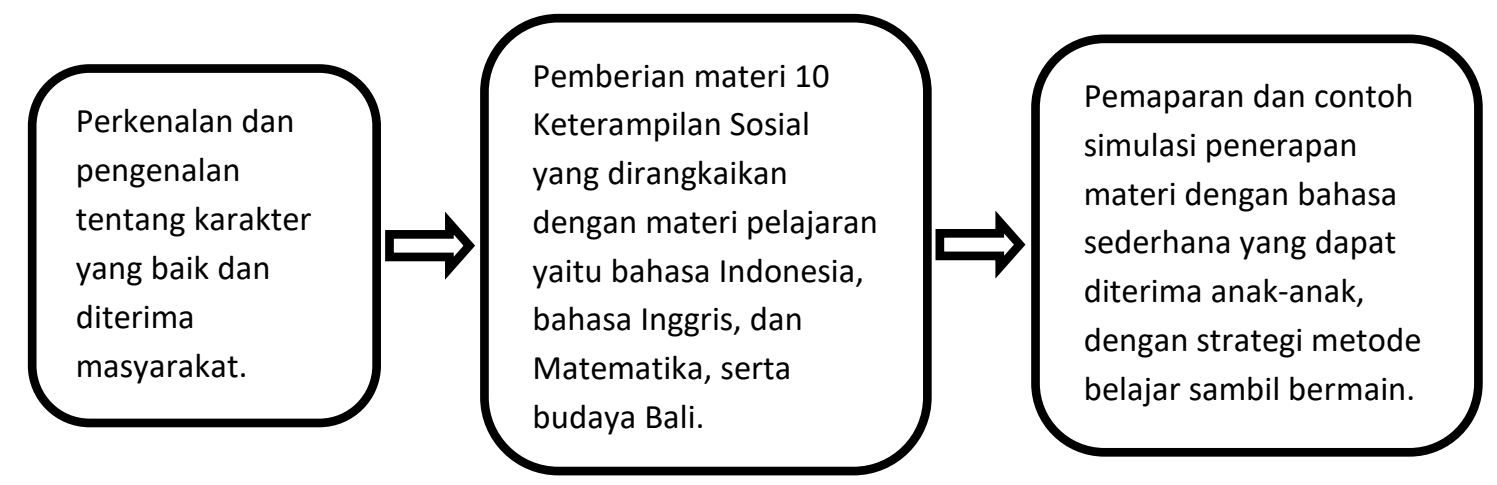

Gambar 1 Alur Kerja Keseluruhan Kegiatan Pengabdian Masyarakat 
sebuah proses pendidikan yang bertujuan untuk membantu siswa menemunkan makna dalam pembelajaran akademis yang mereka pelajari melalui keterkaitan setiap pokok bahasan dengan kehidupan mereka sehari-hari yakni yang berhubungan dengan lingkungan pribadi, sosial, dan budaya mereka. Ada delapan elemen penting dalam penerapan CTL menurut Johnson yaitu:

1. Melakukan hubungan yang bermakna (Making Meaningful Connections)

2. Melakukan kegiatan-kegiatan yang berarti (Doing Significant Works)

3. Belajar yang diatur sendiri (Self-Regulated Learning)

4. Bekerjasama (Collaborating)

5. Berpikir kritis dan kreatif (Critical dan Creative Thinking)

6. Mengasuh atau memelihara pribadi siswa (Nurturing The Individual)

7. Mencapai standar yang tinggi (Reaching High Standards)

8. Menggunakan penilaian yang otentik (Using Authentic Assessment)

Definisi lainnya, menurut Trianto (2009, 2011), CTL adalah konsep belajar yang membantu guru mengaitkan antara materi yang diajarkannya dengan situasi dunia nyata siswa dan mendorong siswa membuat hubungan antara pengetahuan yang dimilikinya dengan penerapannya dalam kehidupan mereka seharihari, dengan melibatkan tujuh komponen utama pembelajaran efektif, yakni: konstruktivisme (Constructivism), bertanya (Questioning), menemukan (Inquiry), masyarakat belajar (Learning Community), pemodelan (Modeling), dan penilaian sebenarnya (Authentic Assessment).

Berdasarkan berbagai teori di atas, berikut ini disampaikan model pembelajaran CTL yang telah diaplikasikan ke dalam pendidikan sepuluh keterampilan sosial untuk anak-anak di Desa Seririt, Buleleng, Bali.

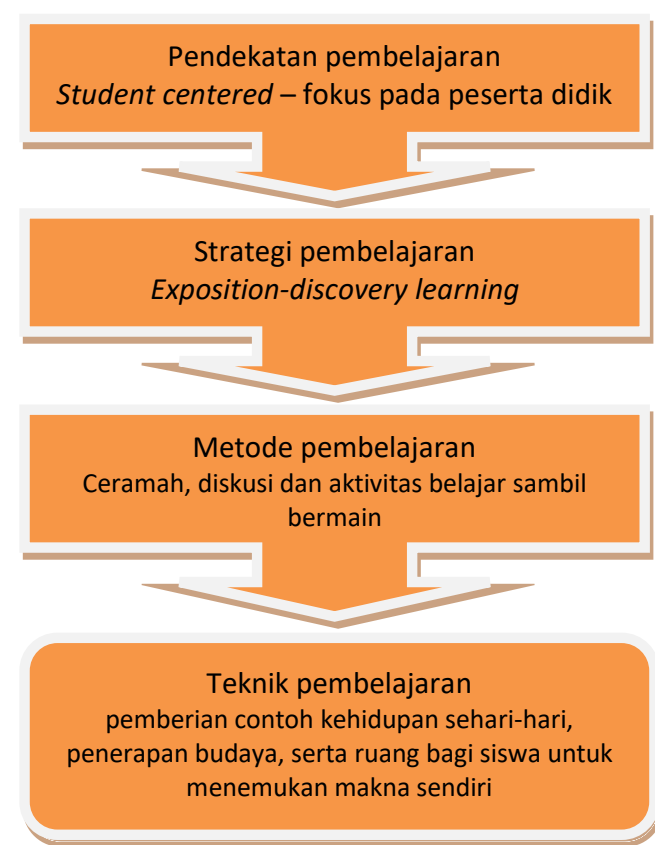

Gambar 2: Model Pembelajaran Contextual

Teaching and Learning dan Penjabarannya dalam Pendekatan, Strategi, Metode, dan Teknik

Berikut disampaikan penjelasan dari diagram di atas. Model pembelajaran CTL di mana pendekatannya terfokus pada siswa agar lebih aktif dalam mengenali karakter yang baik dan menerapkannya sehingga terjadi perubahan yang nyata. Strategi pembelajaran yang digunakan adalah exposition-discovery learning yakni perpaduan antara panduan yang terperinci dari pengajar diikuti dengan pemberian ruang bagi siswa untuk menemukan sendiri (Rowntree \& Connors, 1979). Jadi, disamping ada saat untuk memperhatikan dengan tenang dan mencatat, ada juga saatnya bagi siswa untuk berekspresi menemukan jawaban sendiri atas persoalan-persoalan yang ditampilkan pengajar. Metode pembelajaran yang digunakan adalah ceramah, diskusi, dan aktivitas belajar sambil bermain yang dipandu oleh pengajar. Teknik pembelajaran yang digunakan adalah pemberian contoh kehidupan sehari-hari, penerapan budaya, serta ruang bagi siswa untuk menemukan makna sendiri.

Kegiatan Pengabdian Masyarakat ini melibatkan dosen dan mahasiswa Universitas Terbuka serta guru SD, PAUD, dan TK di Banjar serta Orang Tua Anak dalam pelaksanaan kegiatan sehingga anak-anak dapat mengikuti dengan semangat dan gembira. Pelaksanaan 
kegiatan belajar-mengajar yang diawali oleh rasa senang, riang gembira akan menumbuhkan perasaan optimis, dan percaya diri untuk belajar lebih giat. Dalam kegiatan ini, para Guru SD, PAUD dan TK, dan juga orang tua diajak ikut serta secara interaktif memberikan semangat kepada anak didik/anak-anak mereka misalnya pada saat sesi bermain sambil belajar.

\section{HASIL DAN PEMBAHASAN}

Pelaksana kegiatan diawali dengan sosialisasi oleh tim pengusul dan pembantu lapangan serta mitra pengabdian yang diwakili oleh Ketua Sekeha Teruna Teruni yang dilakukan awal bulan April 2019. Tujuan kegiatan ini yaitu untuk berdiskusi kembali dengan mitra mengenai kegiatan-kegiatan yang akan dilakukan berdasarkan pengamatan awal yang sudah dilaksanakan sebelumnya dengan guruguru SD, PAUD dan TK di Kecamatan Seririt. Awal Mei 2019, pengabdian masyarakat telah mulai dilaksanakan setiap hari minggu, bertempat di Aula Kantor Desa Banjar Tegeha, Kecamatan Seririt, Kabupaten Buleleng. Pada tahap ini, mitra yang terdiri dari anak-anak diberikan bantuan alat belajar yang terdiri dari meja belajar dan alat-alat tulis. Setelah perkenalan singkat dan pembagian alat belajar, anak-anak diberikan penjelasan tentang apa saja yang akan mereka pelajari selama mengikuti pengenalan Pendidikan Sepuluh Keterampilan Sosial (PSKS).

Hari berikutnya, anak-anak mulai diperkenalkan mengenai sepuluh keterampilan sosial melalui pelatihan dan tanya-jawab. Pada kegiatan ini, anak-anak tampak sangat antusias

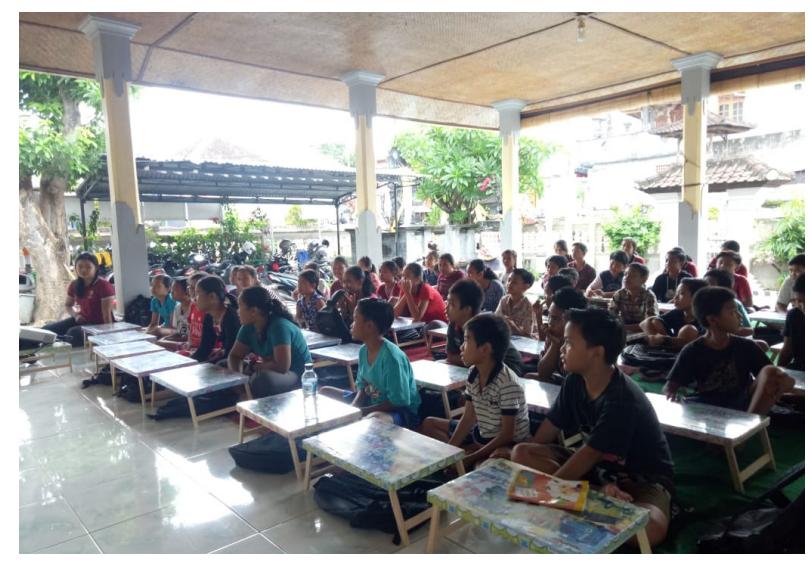

Gambar 3 Kegiatan Penyerahan Meja Belajar dan Alat-Alat Tulis dan sangat gembira. Kegiatan ini dimulai dengan pertanyaan kepada anak-anak, "Siapa ingin cerdas dan berhasil?" kemudian mendengarkan pendapat mereka. Selain itu ditanyakan pula ingin menjadi apa kelak, sehingga mereka diberi kesempatan untuk menyampaikan cita-cita mereka. Setelah itu masuk pada topik mengenal jenis-jenis karakter anak; ada yang koleris, sanguinis, phlegmatis, dan melankolis. Pada slide dijelaskan ciri-ciri dari masing-masing karakter ini, koleris tipe yang tegas, suka memimpin, suka mengatur, bertekad kuat, sifat yang kurang baik yaitu susah minta maaf. Kebaikan tipe sanguinis adalah ceria, suka banyak teman, suka heboh, senang jadi perhatian, cepat minta maaf, namun kekurangannya yaitu sering lupa janji. Lain lagi dengan tipe phlegmatis: suka diatur, bisa menerima pendapat orang lain, jarang protes, namun cenderung pendiam. Dan terakhir tipe melankolis adalah karakter yang sangat teratur, suka kerapian, tergolong pandai, suka mengatur diri-sendiri, tetapi kekurangannya adalah gampang ngambek. Slide presentasi yang ditampilkan saat kegiatan dapat dilihat pada gambar 4 .

Setelah paparan materi, mereka diajak untuk mengenal tipe karakter mereka masingmasing. Apakah mereka termasuk tipe koleris, sanguinis, phlegmatis atau melankolis, serta apa kebaikan dan kekurangannya, serta bagaimana menyeimbangkan kekurangan mereka. Anakanak diajak untuk menemukan bagaimana dengan saling mendukung satu dengan yang lain, mereka memiliki kekuatan untuk maju bersama-sama. Hal ini adalah penjurusan dalam keterampilan sosial.

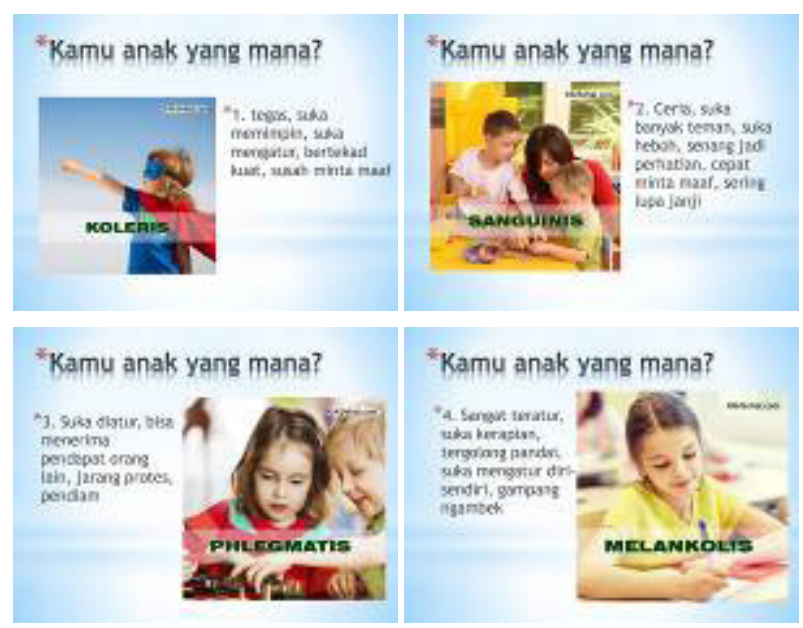

Gambar 4 Tipe-tipe karakter

Warta LPM, Vol. 24, No. 1, Januari 2021 
Hari berikutnya, masuk pada topik utama yakni untuk dapat menjadi cerdas dan berhasil, anak-anak hendaknya memiliki sepuluh keterampilan sosial, yang dijelaskan satu per satu dimulai dengan pernyataan, "Anak yang cerdas itu ..." yang dilanjutkan dengan masing-masing keterampilan sosial. Pertama, bagaimana mengajarkan anak-anak untuk mendengar dengan baik, dimulai dari mendengarkan perkataan keluarga inti: nasihat ayah dan ibu, perkataan kakak dan adik, serta orang tua lainnya seperti: kakek dan nenek serta guru di sekolah. Kedua, anak-anak diajari untuk mengikuti petunjuk. Ketiga, anak-anak diajari untuk mematuhi peraturan, dan dijelaskan juga mengapa harus menaati peraturan. Keempat, anak-anak diajari untuk mengabaikan gangguan dengan fokus melaksanakan apa yang menjadi cita-citanya. Kelima, anak-anak diajarkan bagaimana minta tolong kepada orangorang terdekat ataupun pihak lainnya. Selain bagaimana cara meminta tolong, juga diajarkan bagaimana mengucapkan terima kasih. Kegiatan satu hari penuh membahas lima materi keterampilan sosial diselingi dengan aktivitas belajar sambil bermain.

Hari berikutnya, setelah tanya jawab untuk mengingat materi sebelumnya, dilanjutkan dengan keterampilan sosial yang keenam yakni, anak-anak diajarkan bagaimana menyimak dengan baik serta tidak memotong pembicaraan orang lain. Ketujuh, anak-anak diajarkan untuk menghormati atau menghargai orang-orang sekitar. Kedelapan, anak-anak diajarkan bersikap tenang di setiap keadaan atau keramaian. Kesembilan, anak-anak diajarkan bertanggung jawab terhadap apa yang dikerjakan. Kesepuluh, anak-anak diajarkan untuk selalu berbuat baik.

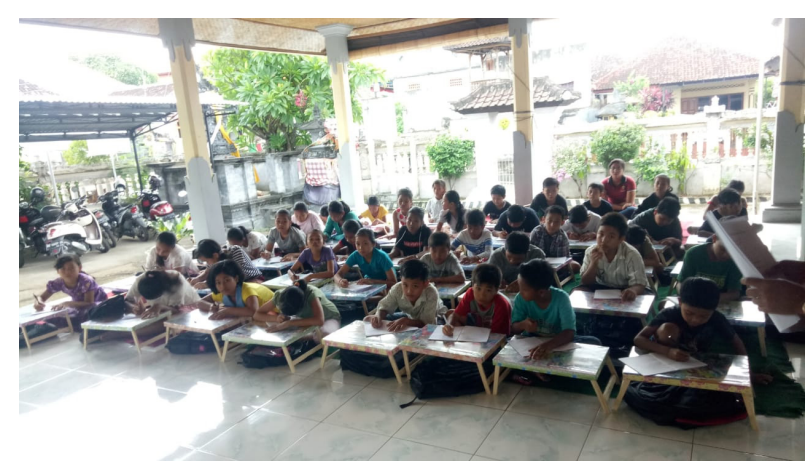

Gambar 5. Paparan Materi Pengenalan Sepuluh Keterampilan Sosial
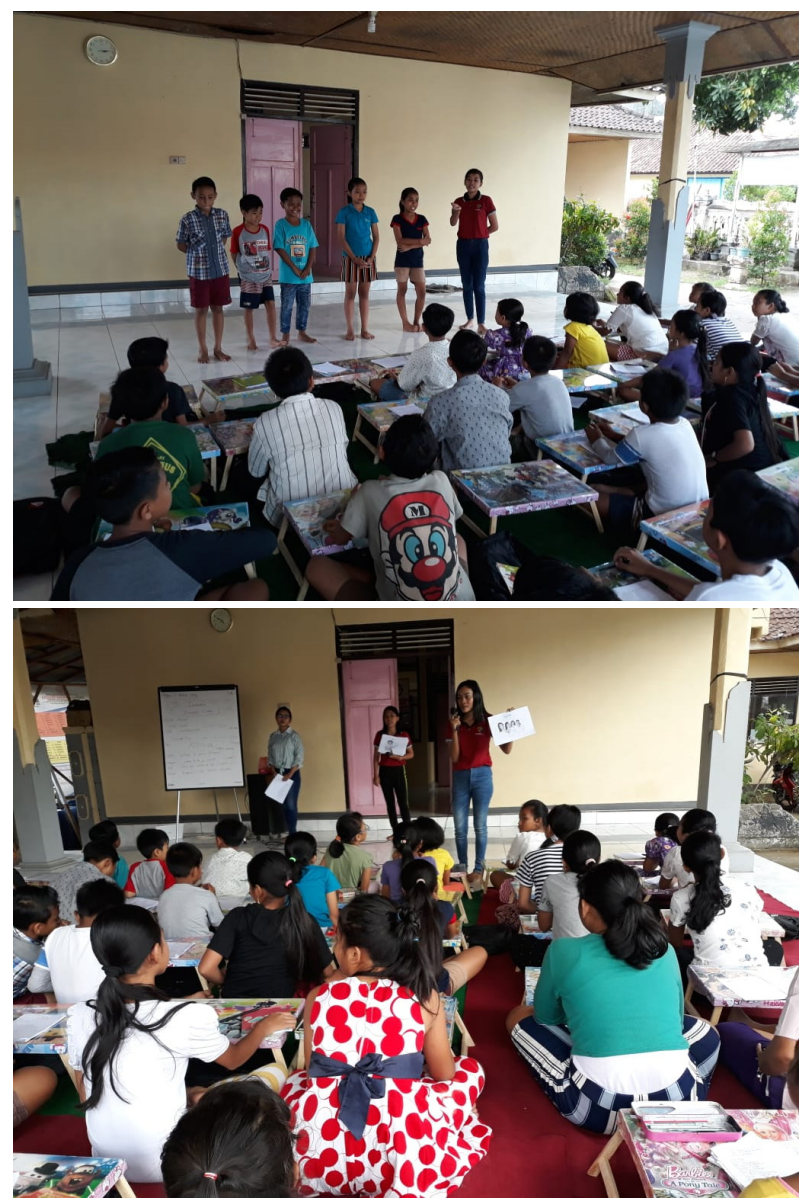

Gambar 6 dan 7 Evaluasi Pengenalan Sepuluh

Keterampilan Sosial melalui Tanya-Jawab

Setelah paparan materi sepuluh keterampilan sosial, acara dilanjutkan dengan sesi tanya jawab dengan anak-anak. Selain menjawab pertanyaan dari anak-anak yang mau bertanya, kepada anak-anak juga diberikan pertanyaan tentang materi yang sudah disampaikan sehingga memantapkan pemahaman mereka. Kegiatan pengenalan lima bagian terakhir dari keterampilan sosial dilakukan juga dilaksanakan selama sehari penuh. Anak-anak peserta PSKS ini mengikuti dengan gembira karena materi yang disampaikan dengan metode yang membuat mereka tidak gampang jenuh, ada selingan permainan dan kuis yang disertai dengan hadiah menarik.

Selain sesi tanya jawab, untuk melatih penerapan sepuluh keterampilan sosial anakanak sekolah dasar dilakukan praktik berupa kegiatan cerdas cermat. Untuk menguatkan penerapan keterampilan sosial yang sudah dipelajari, ditambahkan aktivitas kegiatan budaya berupa belajar menganyam bambu 
bagi anak laki-laki, dan majejaitan bagi anak perempuan untuk membuat sarana upakara (keagamaan) seperti Gambar 8, 9, 10, dan 11. Pada aktivitas ini, mereka juga dipandu bagaimana bekerja dalam kelompok, saling tolong-menolong, mau mendengarkan pendapat orang lain, dan juga memberikan ungkapan apresiasi serta terima kasih.

Serangkaian dengan kegiatan, penerapan budaya yang dilaksanakan meliputi pengenalan tentang mejejahitan (membuat upakara sarana persembahyangan) bagi anak-anak perempuan dan membuat klatkat (anyaman bambu) bagi anak laki-laki. Pada saat pelaksanaan kegiatan budaya ini, anak-anak juga menggunakan pakaian adat madya, yaitu pakaian tradisional Bali untuk mengikuti kegiatan pertemuan semiresmi/kasual, kegiatan persiapan upacara, dan berbagai kegiatan yang sifatnya ringan, non formal. Selain itu, tim pelaksana pengabdian masyarakat juga memberikan materi berupa dongeng tradisional Bali, masatua, di mana anak-anak Desa Seririt menyimak dengan senang cerita-cerita rakyat yang disampaikan oleh kakak-kakak mahasiswa yang turut serta dalam kegiatan pengabdian masyarakat. Konsep ini juga pernah dilaksanakan sebelumnya oleh (Putri, Sumartini, \& Suniantara, 2018) dengan bahasa yang berbeda yaitu bahasa Inggris, dengan nama Belajar Bahasa sambil Bernyanyi dan Bercerita (BBSBB), di sebuah panti asuhan, di mana mereka juga diajak mendengarkan cerita secara interaktif dan bernyanyi, di mana terdapat proses belajar sambil bermain juga.

Kegiatan penerapan budaya sebagai salah satu teknik pembelajaran sepuluh keterampilan sosial dilaksanakan dengan berpedoman pada pengenalan terhadap budaya sendiri yakni budaya Bali. Hal ini dilandasi oleh semboyan salah satu tokoh Bali yakni Prof. Dr. Ida Bagus Mantra, yang dahulu adalah Guru Besar di Unversitas Udayana Denpasar dan juga Gubernur Bali. Beliau menyatakan bahwa "Menemui diri sendiri adalah sumber kreativitas dan kesejahteraan hidup” (Agastia, 2006). Hal penting lain yang disampaikan oleh Mantra (1996) adalah tentang revitalisasi budaya, yang disampaikan pada Pesan-Pesan Pada Upacara
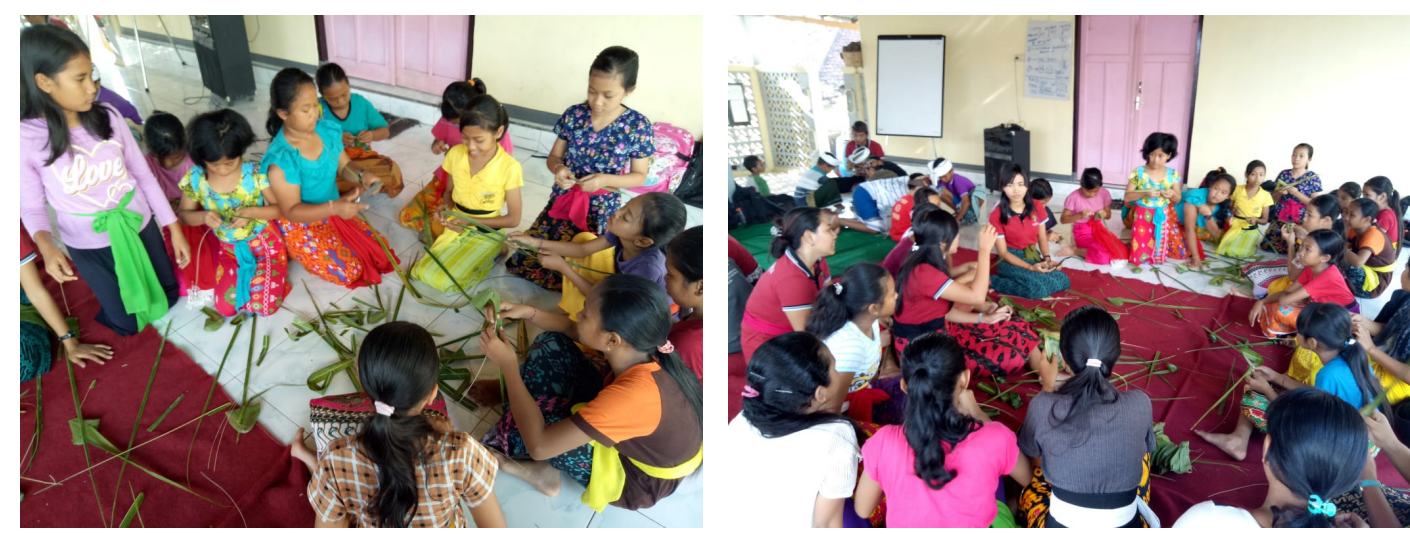

Gambar 8 dan 9 Majejaitan
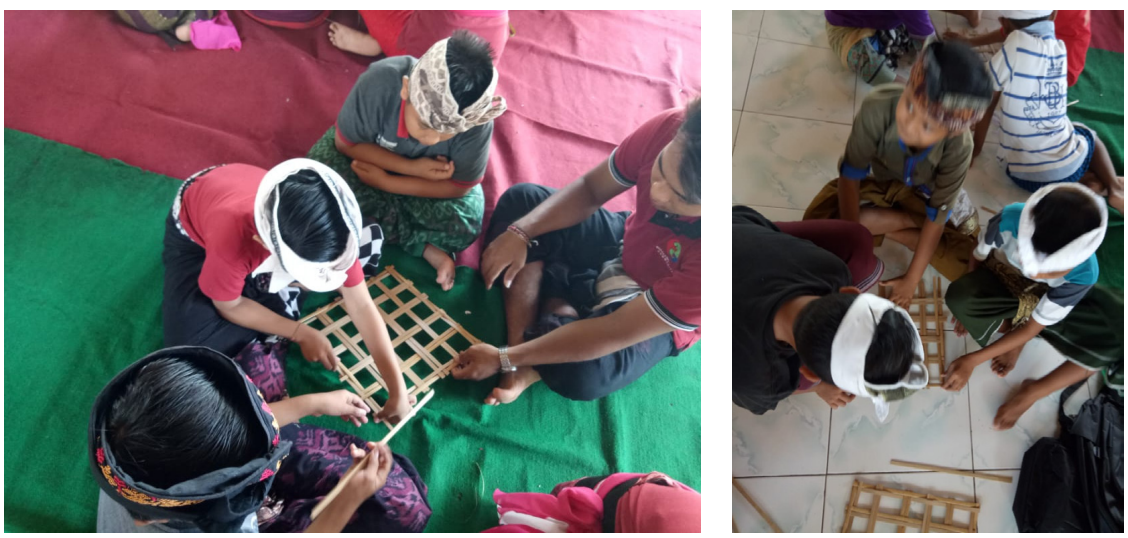

Gambar 10 dan 11 Membuat Klatkat (Anyaman Bambu) 
Purnabhakti (8 Mei 1993). Disampaikan bahwa seiring berjalannya waktu, lingkungan dan peradaban berubah, dan muncul faktor-faktor yang membawa disintegrasi baru terhadap kebudayaan. Masyarakat dengan budayanya akan menghadapi tantangan baru yang harus diterima dengan mengadakan adaptasi dan perubahan seperlunya yang tetap dilandasi oleh nilai-nilai budaya yang telah dimiliki, serta tetap memelihara kesatuannya yang esensial, unsur karakteristik serta arah yang masih sama. Bertahannya sebuah kebudayaan adalah sepanjang masyarakat dan para cendekiawannya merasakan kepuasan hidup dirinya dengan nilainilai yang mendasar, yang diwarisi dengan nilainilai budaya tersebut dapat disegarkan kembali (revitalisasi) melalui proses yang sangat teliti yaitu dengan reinterpretasi, reintegrasi, dan adaptasi.

Materi tentang sepuluh keterampilan sosial juga disampaikan kepada orang tua, yakni warga Desa Banjar Tegeha, Kecamatan Seririt, Kabupaten Buleleng menimbang orang tua adalah pendidik yang utama dalam keluarga. Berkat para orang tua, karakter anak dibentuk dan dibangun menjadi pribadi yang unggul yang menjadi harapan bangsa di masa mendatang.

Pengukuran keberhasilan hasil pelaksanaan pengabdian masyarakat ini telah dilakukan dengan menggunakan metode CIPP yang digagas oleh Stufflebeam, (2007), yakni context, input, process, dan product. Gambar 12 berikut ini adalah pemetaan proses penilaian dengan metode CIPP dan penjabarannya:
Penjelasan evaluasi kegiatan pengabdian masyarakat ini lebih terperinci dijelaskan dengan menjawab empat pertanyaan sebagai berikut.

1. Apa yang harus dilakukan? Menentukan kebutuhan dan tujuan.

Kebutuhan untuk membentuk karakter anak-anak yang kelak menjadi generasi penerus bangsa. Tujuan pelaksanaan pengabdian masyarakat adalah untuk membantu orang tua, pengajar, dan anakanak warga Desa Seririt, Buleleng, Bali, khususnya di bidang pendidikan karakter, dalam hal ini pendidikan dasar sepuluh keterampilan sosial untuk anak-anak usia taman kanak-kanan dan sekolah dasar. Hal ini menjawab dua rumusan masalah yang menjadi pokok pencarian solusi dalam program pengabdian masyarakat ini.

2. Bagaimana kita melaksanakannya? Menentukan pendekatan yang paling tepat untuk memenuhi kebutuhan-kebutuhan yang telah teridentifikasi.

Pendekatan yang digunakan adalah pendekatan yang terfokus pada siswa, Student Centered, di mana karakter siswa yang dibentuk menjadi pribadi yang cerdas dan berakhlak mulia. Siswa diajak lebih aktif mendalami sepuluh keterampilan sosial yang diajarkan dengan banyak berdiskusi dan sharing tentang kehidupan seharihari. Dengan demikian siswa menemukan sendiri makna sepuluh keterampilan sosial

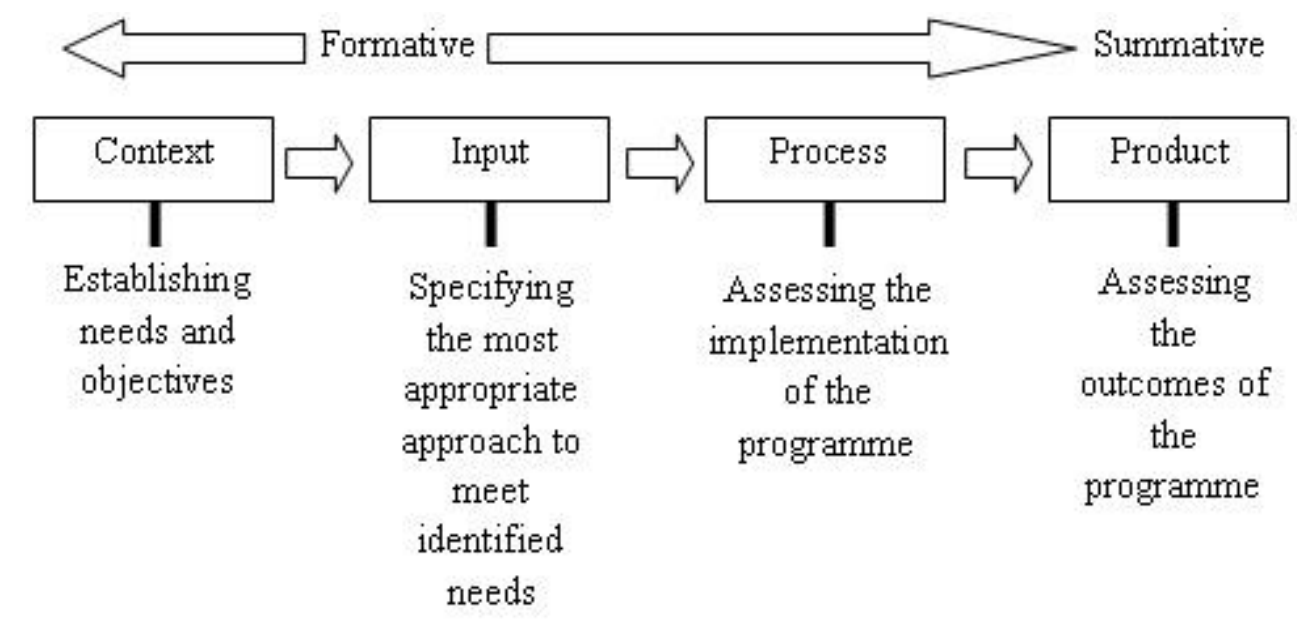

Gambar 12. Metode CIPP 
tersebut dan menumbuhkan niatnya sendiri untuk melaksanakannya.

3. Apakah dikerjakan sesuai rencana? Meninjau kembali implementasi dari program.

Pelaksanaan program Pendidikan Dasar Sepuluh Keterampilan Sosial untuk anak-anak usia sekolah dasar ini telah dilaksanakan dengan baik dan sesuai rencana. Hal ini dapat dilihat dari tersampaikannya materi secara utuh dan terdapat peningkatan sikap dan perilaku anak-anak yang mengikuti kegiatan pendidikan dasar ini. Secara umum, pada saat kegiatan sesi budaya dan belajar sambil bermain, mereka tampak melaksanakan hal-hal yang disampaikan pada materi sepuluh keterampilan sosial.

4. Apakah program yang dilaksanakan berhasil? Mengukur outcome yang dihasilkan dan membandingkannya pada hasil yang diharapkan.

Memperhatikan secara umum pelaksanaan kegiatan Pendidikan Dasar Sepuluh Keterampilan Sosial untuk anak-anak usia sekolah dasar ini, program telah berhasil dilaksanakan. Hal ini dilihat dari perubahan perilaku anak-anak sejak sebelum mengikuti pendidikan dasar sepuluh keterampilan sosial, hingga selesai mengikuti program. Penilaian keberhasilan kegiatan ini dilihat pada perilaku anak-anak yaitu lebih percaya diri mampu menyelesaikan tugas-tugas yang diberikan sebagai rasa tanggung jawab, penuh sopan santun dengan tidak berkata kasar, mau mendengarkan orang tua dan teman sebaya, mau mentaati aturan di saat tim memberikan penjelasan dan kegiatan pengenalan sepuluh keterampilan sosial, bekerja sama dengan teman-teman pada saat kegiatan budaya seperti mejejaitan dan membuat klatkat, dan mendapat pengetahuan baru tentang komunikasi dan budaya, hal ini membuat mereka semakin bangga terhadap budaya Bali yang dimiliki. Para orang tua juga memperoleh tambahan pengetahuan untuk membimbing dan membangun karakter anak-anak mereka dengen memberikan keteladanan didalam keluarga seperti mengucapkan tolong pada anak sendiri dan keluarga lainnya pada saat meminta diambil suatu barang dan mengucapkan terima kasih disaat setelah dibantu.

\section{SIMPULAN}

Berdasarkan uraian pada ketiga bagian yang sebelumnya yakni pendahuluan, metode serta hasil dan pembahasan, dapat disimpulkan bahwa pembangunan karakter anak-anak di wilayah Kecamatan Seririt, Kabupaten Buleleng melalui Pendidikan Sepuluh Keterampilan Sosial (PSKS) kepada anak - anak dilaksanakan dengan menggunakan metode pembelajaran yang terstruktur berdasarkan teori-teori pembelajaran yang ada, serta diimplementasikan dengan merangkaikan kegiatan budaya, serta belajar sambil bermain dalam prosesnya. Sharing pengetahuan tentang pendidikan karakter kepada para orangtua di wilayah Kecamatan Seririt, Kabupaten Buleleng dilaksanakan dengan mengajak turut serta dalam keseluruhan program Pendidikan Sepuluh Keterampilan Sosial baik yang untuk anak-anak maupun sesi orang tua secara tersendiri. Modul dibagikan kepada orang tua dan guru-guru sekolah sebagai acuan mereka untuk pendidikan yang berkesinambungan. Hasil keluaran dari kegiatan pengabdian masyarakat ini adalah perubahan sikap anak-anak yaitu menjadi lebih santun, terbiasa mengucapkan salam, terbiasa meminta tolong dengan ucapan yang baik, mengucapkan terima kasih, tertib, tidak suka mengganggu teman, dan tidak suka mengejek atapun mengucapkan perkataan yang tidak sopan. Anak-anak menjadi lebih fokus dan lebih semangat belajar.

\section{UCAPAN TERIMA KASIH}

Pada kesempatan ini tim pelaksana Pengabdian kepada Masyarakat ingin mengucapkan terima kasih yang sebesarbesarnya kepada Universitas Terbuka sebagai lembaga yang mendanai kegiatan PKM ini. Kami juga mengucapkan terimakasih kepada mitra yang telah berkenan berpartisipasi dalam kegiatan kali ini. 


\section{DAFTAR PUSTAKA}

Agastia, I. (2006). Menemui Diri Sendiri Percikan Pemikiran Prof. Dr. Ida Bagus Mantra. Denpasar: Yayasan Dharma Sastra.

Arends, R. I. (2012). Learning to Teach (9th Ed). New York: The MacGraw-Hill Companies Inc.

Hulukati, W. (2015). Peran Lingkungan Keluarga Terhadap Perkembangan Anak. MUSAWA, 7(2), 265-282. Retrieved from https://media.neliti.com/media/publications/114008-ID-peranlingkungan-keluarga-terhadap-perke.pdf

Izzaty, R. E. (2012). Pentingnya Pendidikan Karakter pada Anak Usia Dini : Sudut Pandang Psikologi Perkembangan Anak. Jurnal Pendidikan Karakter, 1(1), 1-9. Retrieved from http://staffnew.uny. ac.id/upload/132206556/lainlain/Pentingnya+Pendidikan.pdf

Johnson, E. B. (2012). Contextual Teaching and Learning: What It Is and Why It's Here To Stay. Thousand Oaks, California: Corwin Press, Inc., A Sage Publications Company.

Karo-Karo, D. (2014). Membangun Karakter Anak dengan Mensinergikan Pendidikan Informal dengan Pendidikan Formal. Elementary School Journal Pgsd Fip Unimed, 1(2), 1-13. Retrieved from https://jurnal.unimed.ac.id/2012/index.php/elementary/article/viewFile/1322/1083

Maemonah. (2012). Aspek-Aspek dalam Pendidikan Karakter. FORUM TARBIYAH, 10(1), 30-42.

Mantra, I. B. (1996). Landasan Kebudayaan Bali. Denpasar: Yayasan Dharma Sastra.

Munif Chatib. (2019). Gurunya Manusia. Bandung: Kaifa.

Putri, D. R., Sumartini, N. L. P. U., \& Suniantara, K. P. (2018). Belajar Bahasa Sambil Bernyanyi dan Bercerita di Panti Asuhan Anugerah Gereja Bala Keselamatan Denpasar. Widyabhakti Jurnal Ilmiah Populer, 1(1), 13-18.

Ramdhani, M. A. (2014). Lingkungan Pendidikan dalam Implementasi Pendidikan Karakter. Jurnal Pendidikan Universitas Garut, 8(1), 28-37.

Rowntree, D., \& Connors, B. (1979). How to Develop Self-Instructional. England: The Open University.

Sanjaya, A. A. N. A., \& Juliarthana, I. N. H. (2019). Pemanfaatan Bale Banjar sebagai Ruang Kreativitas Anak Muda di Kota Denpasar. Sustainable, Planning and Culture (SPACE) : Jurnal Perencanaan Wilayah Dan Kota, 1(1), 26-32. Retrieved from https://ejournal.unhi.ac.id/index.php/space/ article/view/261/241

Saputro, I. W. (2017). Penanaman Pendidikan Karakter di Lembaga Pendidikan Non-Formal (Studi Kasus di Homeschooling Group Khairu Ummah, Bantul). Jurnal At-Ta'dib, 12(1), 19-42.

Sawitri, N. P. A., \& Nugrahandika, W. H. (2017). Tipologi Perkembangan Pemanfaatan Lahan Bale Banjar dan Faktor-Faktor yang Memengaruhinya Studi Kasus Kota Denpasar, Provinsi Bali. In Seminar Nasional SPACE \#3 (pp. 352-376).

Stufflebeam, D. L. A. J. S. (2007). Evaluation Theory, Models, and Applications. San Francisco: John Wiley \& Sons, Inc.

Sudaryanti. (2012). Pentingnya Pendidikan Karakter bagi Anak Usia Dini.Jurnal Pendidikan Anak, 1(1), $11-20$.

Suryawati, P. (2018). Reaktualisasi Fungsi Bale Banjar di Kota Denpasar. Dharmasmrti: Jurnal Ilmu Agama Dan Kebudayaan, 18(1), 62-70. Retrieved from https://ejournal.unhi.ac.id/index.php/ dharmasmrti/article/view/103/81

Tanu, I. K. (2017). Pentingnya Pendidikan Anak Usia Dini Agar Dapat Tumbuh dan Berkembang sebagai Generasi Bangsa Harapan di Masa Depan. ADI WIDYA: Jurnal Pendidikan Dasar, 2(2), 19-29. 
Suwardika, dkk - Pendidikan Sepuluh Keterampilan Sosial untuk Anak-Anak ...

Trianto. (2009). Mendesain Model Pembelajaran Inovatif Progresif. Jakarta: Kencana Prenada Media Group.

Trianto. (2011). Model-Model Pembelajaran Inovatif Berorientasi Konstruktivistik: Konsep, Landasan Teoritis-Praktis dan Implementasinya. (Sunarni, Ed.) (Cetakan 5). Jakarta: Prestasi Pustaka.

Wibowo, T. (2018). Success Begins with Characters; Revolusi Pendidikan Karakter. Jakarta: Pendidikankarakter.com. 